\title{
Papillon Lefevre syndrome
}

\author{
Kaushal Mahendra Shah, ${ }^{1}$ Amol karagir, ${ }^{1}$ Rajesh Koppikar, ${ }^{2}$ Shridevi Adaki ${ }^{3}$
}

${ }^{1}$ Department of Oral Medicine, Diagnosis \& Radiology, Bharati Vidyapeeth Deemed University Dental College, Sangli, Maharashtra, India

${ }^{2}$ Department of Periodontics, Bharati Vidyapeeth Deemed University Dental College, Sangli, Maharashtra, India ${ }^{3}$ Department of Oral Medicine and Radiology, Bharati Vidyapeeth Deemed University Dental College, Sangli, Maharashtra, India

\section{Correspondence to}

Dr Kaushal Mahendra Shah, thirty2creations@gmail.com
To cite: Shah KM, karagir A, Koppikar R, et al. BMJ Case Rep Published online: [please include Day Month Year] doi:10.1136/ bcr-2013-008989

\section{DESCRIPTION}

A young boy presented to the department of oral medicine and radiology, with a chief complaint of pain and mobility of the lower posterior teeth and difficulty in mastication. Clinical history as revealed by his mother was that he had normal development and eruption of deciduous teeth, but started losing teeth by the age of 3 years. She also noticed that his gingiva would become red, and swollen, and bleed easily, and emit foul smell. After exfoliation, the inflammation subsided and gingiva appeared healthy. But then with the eruption of permanent dentition, the whole process repeated and there was premature exfoliation of the permanent upper first molars. Medical history was non-contributory. Parents did not have a consanguineous marriage. The parents and other family members were not affected. Pregnancy and delivery of the child were normal. General examination revealed thin built, steady gait, no physical or mental developmental impairment. Extraoral examination revealed sharply demarcated psoriasiform, erythematous keratotic plaques involving the entire surface of palms and soles and extending onto the dorsal surfaces of hands and feet (figure 1), emanating a foul smell, which were present since childhood. Intraoral examination revealed gingival inflammation, deep periodontal pockets especially in mandibular molar regions, and mobility of the mandibular first molars. Halitosis was also present. Rest of the oral mucosa appeared normal. Orthopantomograph (figure 2) revealed generalised periodontitis, missing maxillary first molars and alveolar bone loss with mandibular first molars and incisors. On the basis of these clinical and radiographical findings, a diagnosis of Papillon Lefevre syndrome ${ }^{1}$ was made.

Patient has been prescribed kerotolytic preparations containing $20 \%$ salicylic acid for the skin lesions. Periodontitis is usually difficult to control. Teeth involved in alveolar bone degeneration are

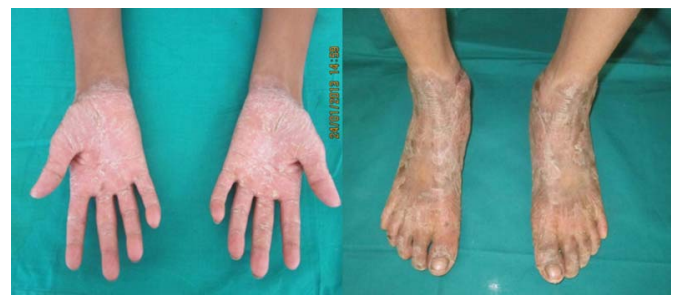

Figure 1 Hands and feet.

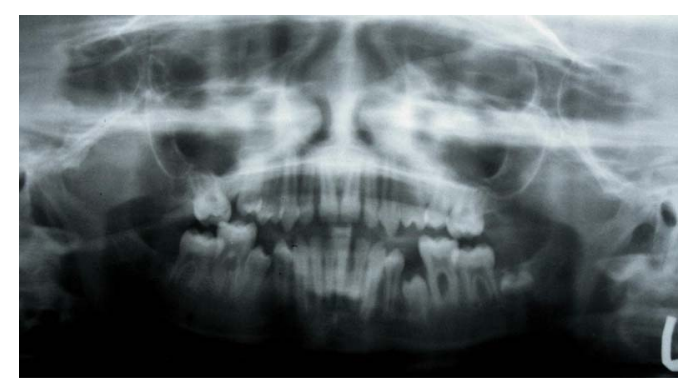

Figure 2 Orthopantomograph.

planned to be extracted and fixed dental prosthesis will be fabricated instead.

\section{Learning points}

- Need to differentiate Papillon Lefevre syndrome (PLS) from other diseases that show severe periodontitis and dermatological lesions, like Haim Munk syndrome ${ }^{2}$ and prepubertal periodontitis.

- Onset at a young age and classic incisor-molar alveolar bone loss in conjunction with palmoplantar keratosis points towards the diagnosis of PLS.

- PLS threatens children and their parents with the prospect of edentulism if left untreated. Hence, early diagnosis and intervention is essential. Awareness of this syndrome is essential if the dentist is to provide an appropriate and comprehensive dental care.

Contributors All authors contributed equally to the article. All the authors were involved in research, background work, preparing the manuscript and review of the manuscript. All the authors approved the final draft of the article.

Competing interests None.

Patient consent Obtained.

Provenance and peer review Not commissioned; externally peer reviewed.

\section{REFERENCES}

1 Gorlin RJ, Sedano H, Anderson VE. The syndrome of palmarplantar hyperkeratosis and premature periodontal destruction of the teeth. J Pediatr 1964;65:895-908.

2 Hart TC, Hart PS, Michalec MD, et al. Haim Munk syndrome and Papillon Lefevre syndrome are allelic mutation in cathepsin C. J Med Genet 2001;38:79-80. 


\section{Images in...}

Copyright 2013 BMJ Publishing Group. All rights reserved. For permission to reuse any of this content visit http://group.bmj.com/group/rights-licensing/permissions.

BMJ Case Report Fellows may re-use this article for personal use and teaching without any further permission.

Become a Fellow of BMJ Case Reports today and you can:

- Submit as many cases as you like

- Enjoy fast sympathetic peer review and rapid publication of accepted articles

- Access all the published articles

- Re-use any of the published material for personal use and teaching without further permission

For information on Institutional Fellowships contact consortiasales@bmjgroup.com

Visit casereports.bmj.com for more articles like this and to become a Fellow 